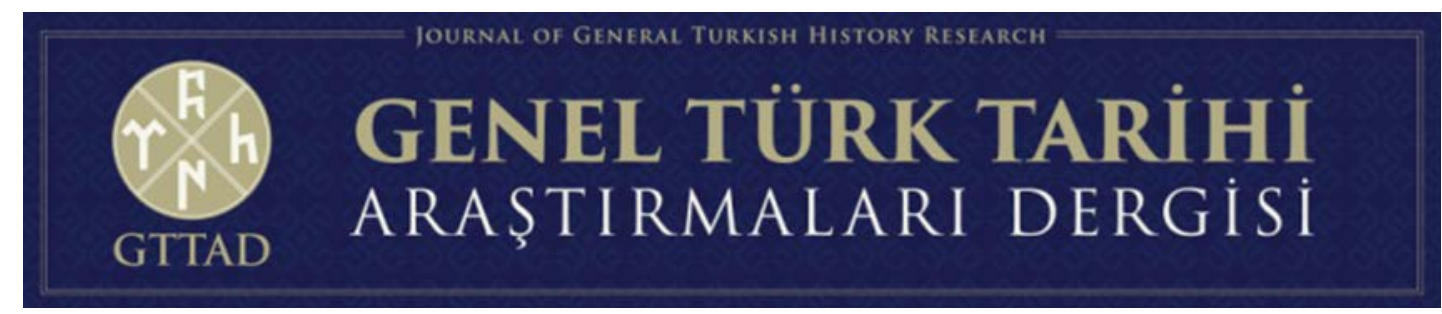

Cilt/Volume 3, Sayı/Issue 6, Temmuz/July 2021, ss. 445-462.

Geliş Tarihi-Received Date: 27.03.2021 Kabul Tarihi-Accepted Date: 24.04.2021

ARASTTIRMA MAKALESI - RESEARCH ARTICLE

\title{
A SINGLE GRAIN OF INDIGO: A READING ON MONGOLS AND TURKS IN THE U.S. LOCAL PRESS (1850-1923)*
}

\section{TEVFİK ORKUN DEVELI**}

\section{ABSTRACT}

In the $19^{\text {th }}$ century, when belief in racial discrimination and superiority could find a response at social and even moral levels, claims about humanity as a biological species turned into some pseudoscientific assumptions. This inevitably constituted a legitimate ground for Orientalist stereotypes such as barbarism, despotism, ignorance, fanaticism, and backwardness directed towards Eastern societies. Orientalism, which has been a baseline for the pride and superiority discourse inherent to the Western society since the second half of the $18^{\text {th }}$ century has been a method for their struggle to examine, learn and reign the East and the Easterners several biased theories and practices which are considered as facts without any doubt. It is possible to approach the American society as a large-scale and heterogeneous sample that represents the West in the analysis of racebased reductionist discourse, which is steered to Eastern civilizations and endeavored to gain legitimacy through Orientalism.

This study aims to reveal the locally-penetrated reflections of a number of racist stereotypes claiming to be scientific and which take their place in the American press since the second half of the $19^{\text {th }}$ century in regards to Turkish and Mongolian identities that are frequently positioned opposite to Western societies in the context of being an 'other'. These two ethnical groups which embrace historically archaic bonds in between has been demonstrated in the local American press as unique sometimes, and neighboring at times; but at the same time, as the carriers of a low-profile culture that can easily be differentiated from Western civilization at every attempt due to its racial specifications.

The image of Central Asia and its peoples in the American local press throughout the $19^{\text {th }}$ and $20^{\text {th }}$ centuries was represented by travel notes, columns, political news, short stories, and funnies. These texts and illustrations, which are mostly of pseudoscientific concerns, were sometimes published simultaneously in different states with a number of old articles and columns were reprinted by the conjuncture of the day. Among these, there are some texts that tried to establish kinship ties between Germans and Mongols based on so-called scientific data obtained from skull measurements during the Great War, thus accusing Germans of being aggressive by nature. The anti-German propaganda that took place in the American local press also reveals that the word Mongolian turned into one of the main reference points of the racist paradigm during this period. Indeed, terms such as Mongol, Mongolian, and Mongoloid have expanded in meaning to characterize all peoples classified as a yellow race by Westerners such as the Chinese and Japanese.

The image of Turks in the American local press offers a common area that can be analyzed in the same context. The texts in question reveal the mentality in which the racist belief that constitutes the basis for hate speech is preserved, but a much harsher and uncompromising style is adopted. This can be explained by the fact that, while the American local press spread orientalist content during the $19^{\text {th }}$ century, and at the same time hosted the anti-Turkish campaigns of the Armenian diaspora throughout the country.

Keywords: Racism, Orientalism, American, Mongol, Turk.

\footnotetext{
* Summary of this study presented orally at the International Symposium of Turcology held in Ulanbator, Mongolia (1-7 June 2018). This is the revised and expanded version of the unpublished paper titled "Mongolian and Turkish Phenotypes in the American Local Press (Late $19^{\text {th }}$ - Early $20^{\text {th }}$ Centuries).

** Dr., Muğla Sttkı Koçman Üniversitesi, Edebiyat Fakültesi, Tarih Bölümü, E-Posta: orkundeveli@mu.edu.tr, ORCID ID: 0000-0003-2768$111 \mathrm{X}$
} 


\section{A SINGLE GRAIN OF INDIGO: A READING ON MONGOLS AND TURKS IN THE U.S. LOCAL PRESS (1850-1923)}

\section{TEK BİR ÇIVIT TANESİ: AMERIKAN YEREL BASININDA MOĞOLLAR VE TÜRKLER ÜZERINE BİR OKUMA (1850-1923)*}

ÖZ

Irksal ayrım ve üstünlüğe yönelik inancın, toplumsal hatta ahlaki düzeylerde karşılık bulabildiği 19. yüzyılda, beşeriyeti biyolojik bir tür olarak ele alan iddialar birtakım sahtebilimsel kabullere dönüşmüştür. Bu durum, Doğulu toplumlara yönelen barbarlık, despotluk, cehalet, fanatizm ve geri kalmışlık gibi Şarkiyatçı basmakalıplara da kaçınılmaz olarak meşru bir zemin sunmuştur. 18. yüzyılın ikinci yarısından itibaren Batı medeniyetine içkin gurur ve üstünlük söylemine dayanak teşkil eden Şarkiyatçılık, Doğu'yu ve Doğuluları gerçekliğinden şüphe edilmeyen bir takım ön yargılı kuram ve pratiklerle inceleme, öğrenme ve onlara hükmetme çabalarına metot oluşturmuştur. Doğulu toplumlara yöneltilen ve modern Şarkiyatçılıkla meşruiyet kazandırılmak istenen rrk temelli indirgemeci söylemin analizinde, Amerikan toplumunu Batı'yı temsil eden geniş ölçekli ve heterojen bir örneklem olarak ele almak mümkündür.

Bu çalışma, öteki olma durumu bağlamında sıklıkla Batı toplumlarının karşısında konumlandırılan Türk ve Moğol kimlikleri hakkında, 19. yüzyılın ikinci yarısından itibaren Amerikan basınında kendisine yer bulan ve bilimsel olma iddiasındaki birtakım ırkçı basmakalıpların eyaletler düzeyindeki yansımalarını ortaya koymayı amaçlamaktadır. Amerikan yerel basınında, aralarında tarihsel olarak kadim bağlar bulunan bu iki etnik grup, kimi zaman özgün kimi zaman ise birbirleriyle akraba fakat sahip oldukları ırksal özellikler sebebiyle Batılı toplumlardan her defasında kolaylıkla ayrıştırılan aşağı bir kültürün taşıyıcıları olarak takdim edilmiştir.

19. ve 20. yüzyılların Amerikan yerel basınında Orta Asya ve halklarının imajı, gezi notları, köşe yazıları, siyasi haberler, kısa öyküler ve karikatürlerle temsil edilmiştir. Ekseriyeti sözde bilimsel kaygılar barındıran bu tarz metin ve görseller bazen farklı eyaletlerde eş zamanlı olarak yayımlanmış bazen de eski makaleler ve köşe yazıları konjonktürel olarak yeniden servis edilmiştir. Bunlar arasında, Büyük Savaş yıllarındaki kafatası ölçümlerinden elde edilen düzmece bilimsel verilere dayanarak Almanlar ile Moğollar arasında akrabalık bağı kurmaya çalışan, böylelikle Almanları doğası gerĕ̆i saldırgan olmakla itham eden metinler bulunmaktadır. Amerikan yerel basınında kendisine yer bulan Alman karşıtı propaganda, bu dönemde Moğol sözcüğünün 1rkçı paradigmanın temel referans noktalarından birine dönüştüğünü de ortaya koymaktadır. Gerçekten de $M o \breve{g o l}$, Moğolluk ve Moğolumsu gibi kavramlar, Çinliler ve Japonlar gibi Batılılar tarafindan sarı ırka mensup olarak sınıflandırılan halkların tümünü niteleyecek biçimde anlam genişlemesine uğramıştır.

Amerikan yerel basınındaki Türk imgesi de yine aynı bağlamda incelenebilecek ortak bir alan sunmaktadır. Söz konusu metinler nefret söylemine dayanak teşkil eden ırkçı inancın aynen korunduğu, bununla birlikte çok daha sert ve tavizsiz bir üslubun benimsendiği bir anlayışı gözler önüne sermektedir. Bu durum, Amerikan yerel basının 19. yüzyılda oryantalist içerik yayarken aynı zamanda Ermeni diasporasının Türkiye karşıtı kampanyalarına da ülke çapında ev sahipliği yapmasıyla açıklanabilir.

Anahtar Kelimeler: Irkçılık, Şarkiyatçılık, Amerikan, Moğol, Türk.

\section{INTRODUCTION}

It can be asserted that a natural impulse for potential discrimination arises in the negotiation process for the acquisition of social identity based on the acceptance that a dominant group (us, the self) defines itself in terms of real or imaginary differences with one or more repressed groups (them, others) ${ }^{1}$ The attractiveness of looking and sounding similar on the people's preferences, which unite them together, also enables to consider xenophobia as a natural attitude. ${ }^{2}$ It can be asserted that this impulse brings an inevitable claim of superiority with itself. Within the artificial groups built on some common denominators utterly devoid of logical ground, the fact that even individuals, who do not know each other at all and have no connection, develop a sense of belonging and display discriminatory reflexes against out-groups offers observable clues as to the nature of both deep-rooted and highly resilient thinking and practices such as racism empirically. ${ }^{3}$ Cognitively, the scapegoating mechanism, which serves to release the emotional tensions accumulated in various kinds, can turn

\footnotetext{
${ }^{*}$ Bu çalıșma, 1-7 Haziran 2018 tarihleri arasında Moğolistan'ın Ulanbator şehrinde düzenlenen Köktürk Yazısının Okunuşunun 125. Yılında Orhun'dan Anadolu'ya Uluslararası Türkoloji Sempozyumu'nda yalnızca sözlü olarak sunulan “Amerikan Yerel Basınında Moğol ve Türk Fenotipleri Üzerine Değerlendirmeler (XIX. Yüzyıl Sonları-XX. Yüzyıl Başları)” başlıklı yayımlanmamış tebliğin gözden geçirilmiş ve genişletilmiş halidir.

1 Jean-François Staszak, “Other/Otherness”, International Encyclopedia of Human Geography, Elsevier Science, Oxford 2009, [Author postprint], p. 43.

${ }^{2}$ David Eagleman, Incognito-Beynin Gizli Hayatı, çev. Zeynep Arık Tozar, Domingo, İstanbul 2013, p. 189.

${ }^{3}$ Peter Weinreich, "Rationality and Irrationality in Racial and Ethnic Relations: A Metatheoretical Framework", Ethnic and Racial Studies, Vol. 8/4, Surrey 1985, p. 502.
} 


\section{TEVFIK ORKUN DEVELI}

the repressed feelings of childhood or the disturbances arising from social role changes into the subject of hostile attitude towards outgroups, by projecting the crime/blame onto other people. ${ }^{4}$ It can be stated that this phenomenon manifests itself much more clearly in racism. Racist ideologies are characterized by a frantic search for traces of common bonds of innate or instinctive nature to legitimize the claim that a racial group has inherent and immutable differences from other such groups. ${ }^{5}$ This provides it an irrational content. Racism has no concrete facts, which are analyzed objectively; it varies over time and between peoples based on multiple factors. It mixes up inherited features with cultural phenomena. It confuses reality and fantasy, language and religion, real and non-existent differences. In its interpretation, it always manipulates the facts for its purposes. The aim here is to prove that the supremacist construct between groups is permanent and cannot be changed. All of these come from the inside, from the essential traits of the body, or the outside, from the climate and geography. ${ }^{6}$

This context provides an insight into the distant past of the understanding that justifies the domination of the West over the East. In the work Airs, Waters, and Places, which is considered to be written by Hippocrates in the late $5^{\text {th }}$ century, it is remarkable that contrast between Europeans and Asians is established, and the latter is particularly standardized when the effects of climate and places on humans are evaluated. With the inclusion of political institutions in the analysis, which deals with character and physiology together, Europeans were portrayed as brave, free, warlike, and willed, while Asian peoples were presented as static, cowardly, and weak people. $^{7}$ The placement of the barbarians, who were described as subordinate to the Greeks by Aristotle on the grounds that they lack reason, in a hierarchical fiction similar to the domination relationship between soul and body can be considered in the same context. ${ }^{8}$ It is possible to expand these examples of antiquity with the works of historians such as Herodotus and Strabo. ${ }^{9}$ Although it is difficult to equate ethnocultural dignity in this period with the concept of racist pride, it should not be forgotten that early modern thinkers such as Bodin, Arbuthnot, Montesquieu, Hume, and Herder were influenced by their predecessors, and irrationality of the race had enormous effects among them. ${ }^{10}$ This reveals that the concept of race ${ }^{11}$, which was considered to be outside of the history of thought until the end of the $19^{\text {th }}$ century, could find a place for itself in the paradigms of Western imagination and even could be one of them.

\section{Theoretical Approach}

The fact that being an 'other' is shaped around reductionist and generic stereotypes as a result of the inequalities in the relations based on power led to the inclusion of racial norms to the mortar of the Orient image built with Western discourses as of the $18^{\text {th }}$ century, and thus racism became the most powerful ideological instruments of the imperial politics at the beginning of the $20^{\text {th }}$ century. ${ }^{12}$ It is possible to read this process of change that the image of the Orient has gone through, theoretically, through Edward Said's Orientalism thesis. Said asserted that Orientalism could be classified into three, namely manifest, latent, and modern, by explaining the Western will to knowledge and seeking of power against the Orient through a historical model. Among these, manifest Orientalism was developed by the West to highlight its superiority over other cultures through an examination of them knowingly and willfully. ${ }^{13}$ The latent form of Orientalism, on the other hand, presents the negative stereotypes such as lust, deviance, perversion, tyranny, negligence, and backwardness attributed to the East until the $19^{\text {th }}$ century in more subtle and irresistible integrity and consistency. ${ }^{14}$ In the latent Orientalism, ${ }^{15}$ which unites all kinds of scholars, thinkers, and writers who assume an essential difference between East and West on a common denominator although there is no offensive style, the reader does not question whether the statement has an objectively valid, historical and geographical epistemological correspondence. ${ }^{16}$ In the $19^{\text {th }}$ century, works such as Georges Cuvier's Le règne animal (1817), Robert Knox's The Races of Man (1850), and Arthur de Gobineau's Essai sur l'inégalité des races humaines (1853) are remarkable in terms of revealing the

\footnotetext{
${ }^{4}$ Derek Hook, "Fanon and the Psychoanalysis of Racism”, Critical Psychology. Juta Academic Publishing, Lansdowne 2004, p. 120; Weinreich, ibid, pp. 501-502.

${ }^{5}$ Henri Tajfel, “Social Identity and Intergroup Behaviour”, Social Science Information, Vol. 13/2, Paris 1974 , p. 84.

${ }^{6}$ Benjamin Isaac, The Invention of Racism in Classical Antiquity, Princeton University Press, Princeton 2006, p. 22.

${ }^{7}$ Hippocrates “Airs, Waters, Places”, Hippocrates, Vol. I, trans. William H. S. Jones, William Heinemann Ltd, London 1957, p. 133.

${ }^{8}$ Alan T. Davies, Infected Christianity: A Study of Modern Racism, McGill-Queen's University Press, Montreal 1998, pp. 4-5.

${ }^{9}$ Isaac, ibid, pp. 11, 58.

${ }^{10}$ Isaac, ibid, p. 60.

${ }^{11}$ Davies, ibid, p. 5; Hannah Arendt, "Race-Thinking Before Racism”, The Review of Politics, Vol. 6/1, Cambridge 1944, p. 36-37.

${ }^{12}$ Staszak ibid, p. 43; Arendt, ibid, p. 36.

${ }^{13}$ Aslı Çırakman, "Oryantalizmin Varsayımsal Temelleri: Fikri Sabit İmgelem ve Düşünce Tarihi”, Doğu Batı, Vol. 5/20, Ankara 2002, p. 183.

${ }^{14}$ Elif N. Balcı Erkan, "Metnin Bilinçaltı: Edward Said’de Örtük Şarkiyatçılık”, Uludă̆ Üniversitesi İlahiyat Fakültesi Dergisi, Vol. 22/2, Bursa 2013, p. 154.

${ }^{15}$ Çirakman, ibid, p 183.

${ }^{16}$ Balcı Erkan ibid, p. 154.
} 
established relationship between the latent Orientalism and racism. ${ }^{17}$ Finally, Modern Orientalism has emerged from the end of the $18^{\text {th }}$ century as a kind of domination and reformation tool that includes efforts to learn, write, think, teach, settle and colonize the East and the Eastern. ${ }^{18}$

If the concepts of the East and the West are moved beyond their geographic boundaries with reading specific to identity, it may be necessary to reclarify who is meant by a Westerner or who cannot be a Westerner. The answers to these questions will necessarily lead to some generalizations. Their consistency is directly proportional to the quantity of the samples. From this point of view, since the concept of the Orient is the production of texts written on it, ${ }^{19}$ as Said put forward, it will be possible to see by whom and how the East is represented in the literature after determining what or where the West is.

Within the period from geographical discoveries to the appropriation of land and establishment of institutions by the American society, considering the demographic range of the European colonies founded in the American continent, it is possible to address the United States of America (U.S.A.) as a heterogeneous sample representing the West. It can be said that from the first moment that the white man set foot in the new world, he exported everything that can come to mind, from his language, culture, spirituality, and daily life practices to these lands on a growing mass scale and built the U.S. on the historical heritage of Europe. The truth is that the U.S. could be argued to imply the opposite of what Europe was up to then, and at least until the World Wars, it looked much more modern than Europe. From this point of view, it is also possible to consider the U.S.A. as the other of Europe, not the political and cultural inheritor. On the other hand, as claimed by Ole Wæver, Europe’s other has become its past since the end of World War II, and this past shall not be allowed to be its future. ${ }^{20}$ Since this points to a break in historical continuity, ${ }^{21}$ the question of whether the image of the Orient was transferred to America as the other of Europe within the same continuity principle before the break-in question still awaits an answer. If Turkish and Mongolian identities are acknowledged as images unique to the Orient, the similarity of their image in American and European societies will indirectly answer this question. While it is known that American society does not only include European immigrants and their descendants, for example, when official migration statistics for the centuries between 1820 and 1920 are considered, the numerical gap between European immigrants and the communities that came to America from the rest of the world and settled here is striking. ${ }^{22}$ Another factor that puts the U.S.A. at the center of this study is the fact that problems with racism have occupied a certain area in American society for one reason or another since the colonial era. This problem, which was among the issues of the founding period of the U.S.A., formed a part of the conflicts between the northern and the southern states during the civil war years (1861-1865), as can be seen in the struggle of black people for civil rights between 1954 and 1968, it also marked the recent history of this country. ${ }^{23}$

If the U.S.A. is accepted as one of the historical successors of Europe, it can be stated that the pure and clean essence of European identity has expanded its mental boundaries that are tried to be protected by excluding those who pollute it. ${ }^{24}$ This legacy inherited by the U.S.A. contains a discourse against the Orient that dates back to the classical period, later took the form of Christianity against Islam, and was replaced by an understanding of barbarism against civilization with the Enlightenment thought. ${ }^{25}$ This discourse, which includes concepts such as despotism, fanaticism, deceit, violence, and eroticism, has been used as a characterization of Central Asia,

\footnotetext{
${ }^{17}$ Edward W. Said, Orientalism, Vintage Books, New York 1978, p. 206.

${ }^{18}$ Çrakman, ibid, p. 183.

${ }^{19}$ Said, ibid, p. 94.

${ }^{20}$ Ole Wæver, “Insecurity, Security, and Asecurity in the West European Non-War Community”, Security Communities, ed. Emanuel Adler, et al, Cambridge University Press, Cambridge 1998, p. 90; Hakan Ö. Ongur, Minorities of Europeanization: The New Others of European Social Identitiy, Lexington Books, New York 2015, p. 63.

${ }^{21}$ Ongur, ibid, p. 63-64.

${ }^{22}$ For numerical data see Historical Statistics of the United States: From Colonial Times to 1970, Bicentennial Ed., U.S. Bureau of the Census, Washington DC. 1975, pp. 105-109.

${ }^{23}$ Liah Greenfeld, Nationalism: Five Roads to Modernity, Harvard University Press, Massachusetts 1994, p. 473; Jacob U. Gordon, "Black Males in the Civil Rights Movement”, The Annals of the American Academy of Political and Social Science, Vol. 569, Philadelphia 2000, pp. 42-43.

${ }^{24}$ Meyda Yeğenoğlu summarizes what is meant by European identity as follows: Edward Said showed in Orientalism (1978) that Europe is not simply a geographical or regional reference, but is inextricably intertwined with cultural signification processes. Geographical distinctions, that is, descriptions such as "lands of civilization" or "lands of barbarians" are border-setting tools. Such markings and boundaries do not exist in our minds in a simple manner: "They" become "they" accordingly, and both their territory and their mentality are designated as different from "ours". This "imaginative geography" is operative in establishment of the sense of identity as a result of marking of the "distance and difference between what is close to it and what is far away". Europe, then, is an idea and an identity, a discursive strategy for establishing difference and identity. See Meyda Yeğenoğlu, "Avrupa Kimliğinin İdeolojik Arka Planı”, Doğu Batı, Vol. 8/31, Ankara 2005, pp. 90-91.

${ }^{25}$ Yeğenoğlu ibid, pp. 91-92.
} 


\section{TEVFIK ORKUN DEVELI}

especially due to the memory of the Mongol invasions. ${ }^{26}$ Similarly, the claim that European values were defended rather than European lands in the face of Ottoman attacks ${ }^{27}$ is the continuation of the intolerance symbolized by the religious and political division between the two sides of the Mediterranean since the times of the Muslim Arab conquests and the Charle Magne. ${ }^{28}$ In this context, it can be said that two communities -the Mongols and the Turks- who have an exceptional place in the Orientalist discourse, meet on common ground in the image of the Orient built by the Westerners. An example of this association can be seen in the statements of François-René de Chateaubriand, who argued that the Turks should be sent back to the Mongolian steppes on the grounds that Turkish society was founded on slavery and polygamy. ${ }^{29}$

Accordingly, if the member of the family of Western nations representing civilization in the face of barbarism, but ironically having an establishment of slavery in their social structure, Americans' perception and reformation of the Orient along the three-stage evolution process of Orientalism is examined, a negative Mongol-Turkish image, which is beyond academic studies and finds an audience at the local level, is in question. It is possible to consider this image, which brings together the stereotypes that are a part of the Western background and the racist presuppositions that claim to be scientific, as the product of modern Orientalist texts that build and reinforce the Orient. American local press organs, on the other hand, can be described as a platform in which the ideological discourse in question is adopted and voiced.

\section{The Image of Mongol}

As of the second half of the $19^{\text {th }}$ century, the texts about Central Asia and Mongols in the American local press are generally composed of the notes of foreign travelers, articles published in European newspapers, scientific papers, political news, short stories, and cartoons. In these texts, controversial information was provided regarding the origins, and distant past of the Mongols, their language, social structure, customs, and daily life were elaborated, and especially their warlike character was highlighted:

"The Chinese Tartars, as you know, are divided into two great nations, resembling each other generally in appearance and manners but differing in language and hostile in history. The Mantchoos and the Mongols... ${ }^{30}$ If the Mongols rank among the greatest warriors of the earth, they are equally to be classed among the most brutal of its savages." ${ }^{31}$

It is clear that the Mongols, who were depicted as the savages of the world in the local press of the period, did not refer to the noble savage, which was idealized with his courage and honesty even though he was raised in a primitive community as represented in Daniel Defoe's Robinson Crusoe (1719) or Jean-Jacques Rousseau's Emilie (1762). ${ }^{32}$ From this point of view, despite there are texts which introduce the Mongols as sentimental people who can be sorry for the death of a mosquito or lacks distressing words such as goodbye time to time ${ }^{33}$, it is possible to consider these as a by-product of Eastern exoticism articulated with the Orientalist understanding. ${ }^{34}$ The primary motivation in this respect can be interpreted as to make the content newsworthy by introducing counter-arguments against the settled opinions to attract the attention of the audience.

An article published in The Sun, one of the American local press organs in 1880, which was based on the travel notes of the Russian geographer Nikolay M. Prejevalsky, includes information on the Mongols in great detail. This long article compared some customs and daily life practices of the Mongols with Europeans:

"The Mongols unlike the natives of the civilized countries have no fixed time for repasts. Everyone eats and drinks as often and just when the fancy takes him. The gluttony of the nomads, according to Col.

\footnotetext{
${ }^{26}$ Adeeb Khalid, "Russian History and the Debate over Orientalism”, Kritika: Explorations in Russian and Eurasian History, Vol. 1/4, Washington DC. 2000, pp. 696-697.

${ }^{27}$ Yeğenoğlu ibid, p. 91.

${ }^{28}$ Silvio Marchetti, "Avrupalıların Gözüyle Türkler: Mitos ve Yanlış Anlaşılma”, Dünyada Türk Imgesi, ed. Özlem Kumrular, Kitap Yayınevi, İstanbul 2005, p. 9; Tevfik Orkun Develi, "Kum Zencileri: Siber Irkçı Söylemde Türk İmgesi ve Tarihsel Revizyonizm (Stormfront.org Örneği)”, Toplum ve Bilim, Vol. 141, İstanbul 2017, p. 226.

${ }^{29}$ Alain Servantie, "Batılıların Gözünde Türk İmajının Geçirdiği Değişimler: Cehennem Teolojisinden Demokrasi Derslerine", Dünyada Türk Imgesi, ed. Özlem Kumrular, Kitap Yayınevi, İstanbul 2005, p. 60-61.

30 "Russian Annexation in Asia”, New-York Daily Tribune, No. XVII/5180, 26 November 1857, p. 6.

31 “Jenghiz Khan”, The Abbeville Press and Banner, No. 51/XXV, 29 May 1878, p. 1.

${ }^{32}$ Murat Topçu, 19. Yüzyıl Rus Edebiyatında Kafkasya Imgesi, Ph.D Thesis, Istanbul University Institute of Social Sciences, Istanbul 2016, pp. 43-45. According to Gerard Delanty, even the noble savage myth by itself is not a criticism of the European society. The emotional sensitivity displayed to the Eastern societies through the noble savage image is a result of the direct attitude of the Western great powers which does not see them as rivals. See Gerard Delanty, Inventing Europe: Idea, Identity, Reality, St. Martin’s Press, New York 1995, pp. 9091.

33 “Odd Mongolian Habits”, The Bolivar Bulletin, No. XIX/5, 20 September 1883, p. 4.

${ }^{34}$ The fact that there is no word equivalent to this phrase is the result of the Mongols' wish to avoid the distressing situation due to parting with someone. Even though there is such a word, they seldom or never use it. Instead a bow and a smile... suffice for nearly all occassions. See. M.W.H., “Unknown Mongols”, The Sun, No. XLVII/217, 4 April 1880, p. 2.
} 

PRESS (1850-1923)

Prejevalsky, is such as we find ascribed to Homer's heroes or to Scandinavian Vikings on their return from a marauding expedition. On certain occasions of solemn festival when the Mongols abandon themselves to the delights of the table, it often happens that one man will bolt, at a single sitting, ten or twelve pounds of mutton. (...) They never eat the flesh of birds or fish. (...) In eating, the Mongols use their hands, never having adopted chopsticks (...) The Mongol, owing everything to his flocks and herds -for these furnish him his food, his clothing, and the felt tent that covers him -concentrates all the energy of which his faculties are capable on the rearing of livestock, so that the care of his own person and of his family becomes a secondary concern. It is a curious fact, however, that notwithstanding the gentleness with the Mongol treats domestic animals, nothing in our eyes would be more barbarous than his method of slaughtering the sheep that are intended for the table. It appears after slitting open the belly of the wretched beast, a man plunges in his hand and squeezes the victim's heart till death ensues. We are told that this operation is sometimes of long duration. (...) The lot of the Mongol woman is far from enviable. (...) The Mongol code recognizes but one legitimate spouse, although it permits the husband to have several mistresses living under the same roof with his legal companion. (...) The concubines must obey the lawful wife. (...) The future happiness of the wedded pair is the promise offered by their horoscope. Not a few matrimonial negotiations are broken off because astrologers find that the stars under which the lovers were born are in opposition., 35

In the second half of the $19^{\text {th }}$ century, the blending of evolutionary principles such as natural selection and struggle for existence with the notion of social progress has spread the supremacist attitude of the white race to the Orientalist texts. ${ }^{36}$ This attitude, which influential in the American local press of the period, has even penetrated the texts which deal with the deep-rooted traditions which have almost become a ritual within the Mongolian cultural heritage. One of them might be being on horseback in the sense that a Mongol, whether on his way from a friends tent at not great distance, or is watching his flocks is almost constantly perched upon a horse or camel is related to his constitutional laziness. ${ }^{37}$ Similarly, Prejevalsky, who highlights the extremely uncleanliness in the outward appearance, states that not only is the use of bath is unknown to them, but they exhibit $a$ profound aversion to the simplest ablutions and refers to the animal kingdom by putting his observation into an evolutionary frame:

"While under all latitudes the miasmatic vapors engendered by standing water are pernicious to the health, the effects of humidity are far more formidable in the case of the Mongol than of any other race. (...) The action of climate, prolonged through thousands of years, has profoundly modified the constitution of the nomad, who like the camel or other desert roaming animals, can only live, or at least thrive, in the countries where the air is charged with somewhat less than average quantity of moisture.”38

The Mongols, who were reflected as people who believe that sword is better than the pen in the texts which were written with racist ideas penetrated to the knowledge on the East, were the subject of texts which explain their physical outlook in great detail in the $19^{\text {th }}$ century American local press. ${ }^{39}$ The following statements were made on the Mongolian major-domo called Samdadchiemba in a text from the travelogue by the French missionary named Évariste Régis Huc (1813-1860), who traveled to the Far East in 1844-1846, published in Washington based Weekly National Intelligencer (1841-1869):

"In his physique, he bore unmistakable traces of his Mongol affinities; he had a deeply bronzed complexion, a great mouth cut in a straight line across his face, a nose insolently turned up like a pug monkey's, two little eyes that twinkled between lids entirely without eye-lashes and a forehead with the skin wrinkled up like sub-ventral hide of an elephant." ${ }^{40}$

In the $19^{\text {th }}$ century, when racist stereotypes are presented along with scientific principles, some questions which the American local press was occupied with had a direct relationship with the Mongols as in the works of the Western scientists who contemplate on the race of Adam. In an article on the probability that Adam was a Mongol, besides numerous direct and humiliating representations such as mentioning the body hair of the black people as wool, use of several indirect racist statements such as highlighting the Mongolian primitiveness through the race of the original man discourse is remarkable. ${ }^{41}$

In the $20^{\text {th }}$ century, the dose of racist discourse in the American local press had increased tremendously. In the 1920s, Americans, who turned their attention to the Pacific with the influence of the ultra-nationalist ideas

\footnotetext{
${ }^{35}$ M.W.H., ibid, p. 2.

${ }^{36}$ James A. Rogers, "Darwinism and Social Darwinism”, Journal of the History of Ideas, Vol. 33/2, Philadelphia 1972, pp. 265-266; Topçu, ibid, pp. 16-17

${ }^{37}$ M.W.H., ibid, p. 2.

${ }^{38}$ M.W.H., ibid, p. 2.

39 “The Chinese Army”, The Wichita Daily Eagle, No. XII/3, 20 November 1889, p. 6.

40 "Notes on New Books", Weekly National Intelligencer, No. 562, 1 May 1852, p. 4.

41 “Was Adam A Negro?”, Aberdeen Herald, No. XIII/46, 17 August 1899, p. 6.
} 
that were on the rise, especially in Japan, contemplated on the race of the Japanese, who has reached a certain population in their own country, and this issue also took place in the local media. In the articles written to categorize the Japanese, the meanings of the words such as Mongol or Mongoloid were expended to mean the general of the yellow race. In an article making some claims about why a Japanese is not white (or why not Mongoloid), the physical characteristics of the Mongols are depicted in detailed images. ${ }^{42}$ Besides, it can be said that the claims made in the article in question were written in a scientific language and an uncompromising style:

"Every peculiarity of humanity has been noted and catalogued, and the anthropologists have finally divided mankind into three very distant races. 1) The Caucasian or white race, 2) The Mongoloid including Eskimos, Indians, Chinese, and Japanese 3) The Negroid race, which covers not only African negroes but also the savages in many of the South Sea Islands. By the rules of science it is impossible for the anthropologists to be fooled. (...) If you have a white color and every other appearance of being a 'white man', but your hair emerges from your scalp perfectly straight, the anthropologists know you have Mongolian blood in your veins (...) It is not a matter of opinion, it is a matter of exact science." 43

In another remarkable article from the same period, the researches of a Japanese scientist named Dr. Tokuyasu Kudo have been the target of criticism. In the article, it is emphasized that the Japanese attribute a role to every outward shred of its Orientalism on their bodies to be acknowledged as the equal of the white race and that they make every sacrifice for this purpose; by comparing various races with each other and with chimpanzees based on muscle structures, fiber tissues, eyelids, mouth and nose shapes, skull and jaw samples of various races, it has been suggested that several types, including Mongols, have distinctive physiological features:

"In Mongols scattering bundles of fibres from this muscle [eyelids] radiate in different ways, accounting for characteristic expressions (...) In the Mongols these muscles are generally difficult to distinguish from one another, are most extensive and coarser, and the fibres are more spread out and fan-shaped along the margin of the jaw. (...) One of the truly astonishing conclusions developed by Dr. Kudo is that the musculature which gives us the beautiful, wide open, and rounded eyes of the beauties of the white races is really more primitive than the musculature which produces the half-closed slant eyes of the Mongols! (...) On the other hand, the musculature which determines the shape of the nose is more primitive in the Mongol and the negro than it is in the white..."44

It is clear that the main concern in this issue is not scientificity. The scientific claim is a tool in line with the positivist spirit of the time used to exclude the non-white other from American society. In this way, it is aimed that the European migrant generation can keep their racial awareness alive. After all, it is possible to consider this emphasis as part of a discourse that claims that the existing tendency to social exclusion is also anticipated by natural laws and that this is the only valid way. ${ }^{45}$

As it can be understood from an article in the newspaper, The Hawaiian Star (1893-1912), one of the American local press, at the beginning of the $20^{\text {th }}$ century, the states with the highest Mongolian population in the U.S.A. were Hawaii, Alaska, and California, and it is reported that in 1900, 945 of every 1000 people living in these states were white, 38 were Mongols, 10 were native and 7 were black. ${ }^{46}$ Although these rates differ in official records, it is noteworthy that the non-white population is indeed denser than the others in the aforementioned states. ${ }^{47}$ On the other hand, based on the fact that 31 of the 38 people who are stated to be Mongol in the article are Chinese and the remaining 7 are Japanese, it can be concluded that the word Mongol is mentioned here not as an identity but as a concept that generalizes the yellow race. ${ }^{48}$ In an article about the origins of the American Navajo Indians, a blue dot, which is claimed to be found in the human spine along with monkeys and gorillas, is one of the distinguishing features of the Mongolian race, an example of a similar approach. ${ }^{49}$ However, there are also texts in which the word Mongol is used to characterize an ethnic group. According to the statistics for the year 1900 included in The Hawaiian Star, the number of Mongols living in the U.S.A. is shown as 86,878 , and they are classified separately from the Chinese and Japanese. ${ }^{50}$ Although this

\footnotetext{
${ }^{42}$ See Illustration 1.

43 "Why A Jap Can Never Be A White Man”, The Washington Times-Herald, No. 1/3, 3 December 1922, p. 4 [img 65].

${ }^{44}$ W. H. Ballou, “Science Explains Why The Japs Have Those Squinty, Almond Eyes”, The Washington Times, No. 11.393, 28 December 1919, p. 6 [img 28]. 
situation points to a conceptual duality, given the references to the animal kingdom or the examples, which are used as a means to discredit Native Americans, it can be stated that there is a belief in the American local press that Mongolness constitutes the legitimate justification of being inferior in one way or another.

\section{The Image of Turk}

The image of the Turkish, reflected in the American local press in the $19^{\text {th }}$ century, was shaped by a distinct ethnic and religious hate speech, unlike the Asian communities that were turned into objects of social anthropological experiments by Westerners. In this context, it can be stated that the question of which race? directed to the Mongolians gave way to what is a Turk? in the case of Turks. The answers to this question were written in racist discourse, but this time far from scientific sensitivity and often without concern for political correctness: He (the Turk) is one of the most terrible lessons in humanity's social life. He has been a nemesis, cyclorama of hell, a day of judgment seven days in the week, a selfish, jealous, divided civilization. That is what the Turk is. ${ }^{5}$

However, between the lines of hate speech ${ }^{52}$ that stigmatizes Turks as anti-heroes of Western civilization, especially in the context of the historical struggle between Islam and Christianity, it is possible to encounter some passages questioning the racial origins of the Turks. In these texts, Turks are generally considered as people belonging to the Turanid race. ${ }^{53}$ In an article in which twelve ethnic and racial groups are compared with each other in terms of their physiological characteristics, among which there are Turks, the representational drawings about the Turks are offered to the readers with pejorative expressions such as the Turkish face surrounded by the familiar fez, reveals the cunning, avaricious and cruel character attributed to this much humiliated family of mankind. ${ }^{54}$

Since the debates about the origin of Turks are closely related to the dimension of belief regarding the opposition between East and West, the distinction about civilization, which is expressed by Westerners to exist between civilized societies and barbarians, can easily turn into a religious struggle between Muslims and Christians in the case of Turks and the status of being an 'other' is identified in this context without excluding the former. In this respect, it is not surprising that the answers given to the question of which race are Turks are referenced to the Bible rather than the sources put forward as scientific evidence:

"The origin of the Turk is buried in absolute obscurity. The Biblical extraction of other races science finds no call to question; they are easily traced to Shem, Ham, and Japheth; the ancestry of Jew, Negro and Englishman is clear, Roman, Greek and Persian, Indo German Semite and Aethiopic. The Bible is indeed the best authority on race extraction, but the Bible knows nothing of the Turk nor of his race. We call it Mongolian and do not know whence he comes, in all probability antediluvian, possibly even aside from the Adamic descent. Of this race are the Tartars, the Chinese i.e. the dominant race in China and India, the modern Turks, and almost beyond dispute, the American Indians. Their own traditions say that their ancestor was suckled by a wolf whom he afterward married, and their children were the Turks. This tradition if not literally true is certainly an inspired allegory for through all his history he has appeared not as an inhuman creature but a non-human creature even three-quarters beast." ${ }^{55}$

An interesting detail about the way the Turks were covered in the $19^{\text {th }}$ century American local press is that the content containing hate speech was mostly written by the Armenian diaspora and they made propaganda for the independence demands of the Armenian separatists in the Ottoman lands. In these texts, it is seen that Armenians are trying to influence the American public opinion to support their political demands, which they expressed as their most natural right. ${ }^{56}$ In the articles published against the Turks in the press, Armenians are mentioned as poor, helpless people deserted by both God and man ${ }^{57}$ It is possible to see clear traces of this discourse in the reactions to the Ottoman government's decision to prohibit the introduction of money collected abroad under the guise of humanitarian aid to prevent support for minority movements. Another striking point here is that the writers who criticized the Ottoman government for this decision have agreed on all hands regarding the statement that the Turkish race and the Turkish religion were against their enemies was present in

\footnotetext{
${ }^{51}$ [Ref. Mr.] Mitchell, “The Inscrutable Turk”, New Haven Morning Journal and Courier, No. LXIII/301, 17 December 1895 , p. 3.

52 Develi, ibid, p. 226.

53 “The Bible as a Guide Book", The Pittsburg Dispatch, No. 44, 31 July 1889, p. 4.

54 “Faces On The Wall”, The National Tribune, No. XIII/20[654], 22 February 1894, p. 8; It is reported that the representative drawings, which are claimed to depict human races around the world, belong to a Scottish painter named William Boyd, who graduated from Edinburgh University Faculty of Fine Arts. These drawings, each 2 feet $(60.96 \mathrm{~cm}$.) long, engraved in white granite, are displayed on the first floor of the new national library. As stated in the article, the drawing depicting Turks together with Egyptians and Arabs is located in the far corner of the south facade of the building. See Illustration 6 .

${ }^{55}$ Mitchell, ibid, p. 3.

56 “The Unspeakable Turk”, Scranton Tribune, No. ?/?, 15 January 1895, p. 3.

57 "No Help For The Armenians", Journal Courier, No. LXIV/12, 14 January 1896, p. 4
} 


\section{TEVFIK ORKUN DEVELI}

the original text. ${ }^{58}$ In a 1919 article in the Grand Forks Herald, one of the largest local newspapers in the North Dakota region, some comparisons of the Baptist V. H. Yessayen which argued that there are no other nations who display such contrast as the Armenians and the Turks and therefore it is natural that there will be a perpetual enmity between the two were included:

"The Armenian belongs to the Aryan, the Turk is a Mongolian. The Armenian is Christian, the Turk is Mohammedan. The Armenian is enterprising and industrious, the Turk is lazy and incompetent. The Armenian has a hunger for the things of the mind: the Turk hates Europe, and the western civilization. What is the record of the Turk? When the Turks crossed over into Europe they converted the whole Balkan Peninsula into a smoking ruin. Constantinople once the University of the East was turned over to the dogs and dervishes. And even the proud Arab, who contributed so much to the civilization was pulled down to the level of a bandit or a beggar. The proverb that 'where the sultan's horsehoof threads there even the grass dies' seems to be true.” 59

From this point of view, it can be said that in this period, when support for the political independence of Armenia was sought before the League of Nations and the great Western powers after the Great War, Turkish fear was used intensely to accelerate the Armenian nation-building. With the thesis of ethnic kinship, which Armenian policymakers tried to impose on European nations, especially through Christianity, a kind of anomaly has emerged, in which Islam can be compared with Aryanism, and religious belonging can be positioned against racial terms and descriptions. Considering that the concept of Turanism was frequently featured in the American local press in the same period, it can be said that racial belonging in Western societies has become a fundamental phenomenon in interpreting past or current political events. While the issue of Turanism points to an absolute acceptance in the debates about the origin of Turks, there are also articles in the American local press that deny the claim that Turks belong to the yellow race and even show them as the white race. An article published in 1854 in a newspaper called The Port Gibson Reveille (185? -1857) with the title "The Career of the Turks" is one of the few examples to defend this thesis:

"The Turks are no new race. It is even asserted that Togarmah, mentioned in Genesis, and afterward in Ezekiel were the same people as the modern Turks (...) In the fourteenth century, a tribe of four hundred families, of the purest Turkish blood entered the Seljouk empire. (...) It is a mistake to suppose the Turks a Tatar or Mogul race. The real Turks are Caucassians. Nor are all the Turks under the dominion of the Sultan. Many of tribes of pure Turks exist in the heart of Asia, and are found up to the very walls of China. Their original seats, however, are supposed to lie around the Altai Mountains. They have always been good warriors, nor do they seem to have degenerated, even on the Danube.”60

At the beginning of the $20^{\text {th }}$ century, there was no change in the claims of the American local press which argue that Turks and Mongols were related or even the same. In these texts, it is argued that Turks lack creative ability, in line with Orientalism's typical static society thesis:

"The Turks in ancient times devastated and conquered with complete success, Attila, Ghengiz, Hulagu, Mangu and Timur were never beaten; but for the last 200 years the Turks have constantly been beaten. Why is this? The primitive Turks were pure barbarians, but unfortunately the Turks of today have imbibed some of the vices of the peoples they have conquered - philosophy from Persia, poetry, literature and religion from the Arabs; some tincture of the arts from the Greeks. These are blots and blemishes on the rude purity and simplicity of the Turanian race, who only knew destruction as their motto."61

In another 1919 article showing Turks as a member of the Mongolian race, it was stated that 1 million 600 thousand Tatars lived in Kazan and the Crimea and that these people, physiologically brown-skinned, oval-faced, black eyes placed obliquely, can be easily distinguished with their unusual costume such as the coiffure over which is worn a tight-fitting calotte, or skull cup. ${ }^{62}$

It can be stated that publications of the $19^{\text {th }}$ century Western press reflected an attitude discrediting the Turks and in the $20^{\text {th }}$ century, Turkishness started to be questioned conceptually within the political atmosphere of the Great War. Accordingly, it was claimed in the American local press of the period that the Turkish are

\footnotetext{
${ }^{58}$ Ibid; “Turkey Defiant”, The Roanoke Daily Times, No. XIV/401, 14 January 1896, p. 4; “Turkey is Stubborn”, The San Francisco Call, No. LXXIX/45, 14 January 1896, p. 2.

${ }^{59}$ Mandatory in Armenia Urged”, Grand Forks Herald, No. 14/125, 26 May 1919, p. 16.

60 "The Career of The Turks", Port Gibson Reveille, No. 3/42, 7 June 1854, p. 1. The word Caucasian here describes not the people of a particular geographical region, but all of the white race. By degeneration is meant the degradation or disappearance of racial features that are often articulated in modern racist rhetoric.

61 “The Clean Fighting Turk”, Goodwin's Weekly, No. 27/40, 14 April 1917, p. 5.

${ }^{62}$ Serbia is Home of Many Tribes of Mongolians”, The Cordova Daily Times, No. XIV/124, 30 April 1919, p. 2.
} 

PRESS (1850-1923)

descendants of a race of Tartar barbarians, and are just as much invaders and oppressors as are the Germans. ${ }^{63}$ Moreover, it has been claimed that the Turkish race has never turned into a Turkish nation and that there is no reciprocity between the Ottoman Turkishness and the Western concept of nation. ${ }^{64}$ In the context of the relationship of national identity with modernity, it can be said that this discourse deliberately implies the backwardness of the Turkish people and indirectly tries to emphasize that the Turks have no place in the modern century. In the texts questioning Turkishness conceptually, the claim that the ethnical origins of persons, such as Enver Pasha and Cemal Pasha, representing the Turkist ideology at the political level are of Polish origin and gypsy $^{65}$ can be considered in this context. These claims went so far as to state that in ancient times the Aryans had been the inhabitants of Turkestan, and the Turanians such as Finns, Hungarians, Lapps, Turks and Mongolians were not the real owners of these lands as nomadic communities. ${ }^{66}$

Along with the National Campaign period, Turkish depictions in the American local press are the subject of a separate study. The success of the Turkish armies in the occupied territories Anatolia and the ensuing Turkish Revolution had a broad repercussion in the American press as well as in the European media. In a newspaper called The Arizona Republican in 1919, it was stated that the Turk does not feel that he was beaten and following the Victory of Dardanelles small boys sang songs narrating the English vomiting blood, that the Turkish people believed that their own judgment was poor in siding with the weaker cause in the war, that they threatened the Westerners with the bluff that if the allies persist in their unjust attitude of sternness, they will become Bolsheviks; however, Turkish politicians are well resigned to the idea of having a mandatory power since it will mean foreign aid and rehabilitation. ${ }^{67}$

Towards the beginning of the $20^{\text {th }}$ century, the fact that even in the simplest news contents enriched with photographs in the American local press, some reducing and generalizing expressions like the typical Turkish can be encountered ${ }^{68}$ is remarkable in terms of showing the resistance to racist stereotypes that have settled in the minds of Western societies and the vitality of the Orientalist perspective towards societies excluded from the family of Western nations. The truth is that the mundane belief that one ton of water may be colored by a single grain of indigo offers important hints regarding the area covered by the fear of Turks in the history of contemporary hate against non-white races and hybridity. ${ }^{69}$

\section{CONCLUSION}

Although American society can be easily handled in the context of multiculturalism, it can be stated that the dominant element in its core is European civilization. Accordingly, it can be stated that since the first colonies established in the New World, not only the political but also the cultural border of the West began to expand. Therefore, the U.S.A. has become one of the new production centers of Orientalist thought, interacting with various types of power, acting as the ethno-cultural inheritor of Europe. It can be stated that there is an ancient, irrationality of the race that can be found in almost every period in the content of the cultural heritage taken over by the U.S.A., and it directly penetrated the texts describing the East in the $19^{\text {th }}$ century. In this context, it is seen that the texts written on the East in the $19^{\text {th }}$-century American press were reflected to the readers as modern Orientalist contents, and they had local equivalents.

Although Turks and Mongols are the representatives of two great Asian civilizations in the eternal struggle between East and West, Turks were not included in detail in Said's Orientalism thesis. On the other hand, based on the relationship between history and politics, it is possible to say that in the context of their relations with the West, Turks are one of the main subjects of texts that contain Orientalist content in practice. The articles in the American local press in the $19^{\text {th }}$ century can be regarded as sources that support this claim openly.

\footnotetext{
63 "Rescuing The Old Testament Lands From The Profane Grasp of The Turks”, The Washington Times, No. 10.609, 4 August 1918, p. ? [img 26]. Towards the end of the Great War, some propagandist articles against the Germans were published in the American local press. In an article written on the genetic causes of Prussian ferocity in June 1918, it was claimed that 90\% of the German population had characteristics of Homo Heidelbergensis, which was claimed to have lived between 350 thousand and 200 thousand years ago. According to the article, the Heidelberg primate is the ancestor of the savage Mongols and Tartars whose successive invasions swept over Germany from Asia. Allegedly, as a result of the invasion, the purity of the German race was spoiled and the Germans lost their progressive, artistic, altruistic and intellectual qualities and turned into savages. In the article, the claim of genetic kinship between Mongols and Prussians was tried to be based on a scientific basis with skull measurements called the broad Teuton type and narrow Prussian type, thus Prussians were introduced as warlike savages by nature. For sample images see Illustration 2-3. For relevant article see W. H. Ballou, "Science Explains the Prussian Ferocity in War”, The Washington Times, No. 10.547, 2 June 1918, p. 2 [img 28].

${ }^{64}$ E. S. Bagger, "The Rise and Fall of The Turkish Empire”, New York Tribune, No. LXXIX/26.502, 8 June 1919, p. 2 [img 82].

"Enver Bey May Be Polish Nobleman”, The Brattleboro Daily Reformer, No. 1/4, 6 March 1913, p. 6; "Enver Pasha Condemned For His Crimes During War By Turkish Court Martial”, The Evening World, Final Edition, 12 July 1919, p. 1.

${ }^{66}$ J. E. Watkins, "Fertile Field For The Archeologist Attacting Attention of Scientists”, The Evening Star, No. 17.002, 13 April 1907, p. 3 [img 23].

${ }^{67}$ Gregory Mason, “Turks Say They’re Unbeaten”, The Arizona Republican, No. XXX/172, 17 October 1919 , p. 5.

68 "Here and There Around The World”, Amarillo Daily News, No. XIII/314, 22 October 1922, p. 7 [img 21].

${ }^{69}$ Develi, ibid, p. 223; Mason, ibid, p. 5.
} 


\section{TEVFIK ORKUN DEVELI}

Since the second half of the $19^{\text {th }}$ century, articles published in American local press organs have undertaken a critical function of consolidating and reproducing the racist stereotypes that exist about Turks and Mongols in the minds of the societies of the Western civilization circle/department. In this context, cunning, deceit, ignorance, fanaticism, tyranny, and similar negative stereotypes attributed to Eastern societies in previous centuries were brought together with racist arguments that were tried to be placed on a scientific basis. As a result, it has been tried to prove that the features that distinguish a Turk or a Mongolian from a white European are not only cultural elements but also physiological features such as skin color, skull shapes, hair follicles, eye, and nose structures. It can be argued that a kind of determinism has been attributed to the backwardness of Eastern societies in the historical process with these differences that are intended to be revealed biologically, and thus, it is tried to legitimize the domination of the West over the East.

When we look at the historical development of the political ideology called white nationalism, with an intention surpassing the concepts of community or nation known until now, within the framework of an understanding the West which not only refer to the geographical boundaries, the texts published in the American press as of $19^{\text {th }}$ century offer proofs of racist hate speech and ethnic violence sources against the non-Western others in terms of their articulation with this ideology and their conceptual boundaries.

\section{BIBLIOGRAPHY}

\section{a. Primary Sources}

“Asiatics in America”, The Hawaiian Star, No. XII/3955, 23 November 1904, p. 4.

BAGGER, Eugene S., "The Rise and Fall of the Turkish Empire”, New York Tribune, No. LXXIX/26.502, 8 June 1919, p. 2 [img. 82].

BALLOU, W. H., "Science Explains the Prussian Ferocity in War", The Washington Times, No. 10.547, 2 June 1918, p. 2 [img. 28].

BALLOU, W. H., "Science Explains Why The Japs Have Those Squinty, Almond Eyes”, The Washington Times, No. 11.39328 December 1919, p. 6 [img. 28].

“Blue Spot on Your Spine? Yes? Then You Are a Mongolian!”, The Omaha Sunday Bee, No. XLII/26, 15 December 1912, p.? [img. 31].

“Enver Bey May Be Polish Nobleman”, The Brattleboro Daily Reformer, No. 1/4, 6 March 1913, p. 6.

"Enver Pasha Condemned For His Crimes During War By Turkish Court Martial”, The Evening World, Final Edition, 12 July 1919, p. 1.

“Faces On The Wall” The National Tribune, No. XIII/20[654], 22 February 1894, p. 8.

Gregory Mason, “Turks Say They're Unbeaten”, The Arizona Republican, No. XXX/172, 17 October 1919, p. 5.

"Here and There Around The World” Amarillo Daily News, No. XIII/314, 22 October 1922, p. 7 [img 21].

Hippocrates “Airs, Waters, Places”, Hippocrates, Vol. I, trans. William H. S. Jones, William Heinemann Ltd, London 1957, pp. 65-137.

Historical Statistics of the US 1975 Historical Statistics of the United States: Colonial Times to 1970, Bicentennial Ed., U.S. Bureau of the Census, Washington DC. 1975.

“How Our Movies Make The Heathen Harder to Convert”, The Ogden Standard-Examiner, No. 52/94, 8 October 1922, p. 4 [img 32].

“Jenghiz Khan”, The Abbeville Press and Banner, No. 51/XXV, 29 May 1878, p. 1.

“Mandatory in Armenia Urged” Grand Forks Herald, No. 14/125, 26 May 1919, p. 16.

M.W.H. “Unknown Mongols”, The Sun, No. XLVII/217, 4 April 1880, p. 2.

“No Help For The Armenians” Journal Courier, No. LXIV/12, 14 January 1896, p. 4.

“Notes on New Books”, Weekly National Intelligencer, No. 562, 1 May 1852, p. 4.

“Odd Mongolian Habits” The Bolivar Bulletin, No. XIX/5, 20 September 1883, p. 4. 
[Ref. Mr.] Mitchell “The Inscrutable Turk”, New Haven Morning Journal and Courier, No. LXIII/301, 17 December 1895, p. 3.

"Rescuing The Old Testament Lands From The Profane Grasp of The Turks", The Washington Times, No. 10.609, 4 August 1918, p. ? [img 26].

“Russian Annexation in Asia” New-York Daily Tribune, No. XVII/5180, 26 November 1857, p. 6.

"Serbia is Home of Many Tribes of Mongolians", The Cordova Daily Times, No. XIV/124, 30 April 1919, p. 2.

“The Bible as a Guide Book”, The Pittsburgh Dispatch, No. 44, 31 July 1889, p. 4.

“The Career of The Turks”, Port Gibson Reveille, No. 3/42, 7 June 1854, p. 1.

“The Chinese Army”, The Wichita Daily Eagle, No. XII/3, 20 November 1889, p. 6.

“The Clean Fighting Turk”, Goodwin's Weekly, No. 27/40, 14 April 1917, p. 5.

“The Unspeakable Turk”, Scranton Tribune, ?/?, 15 January 1895, p. 3.

“Turkey Defiant”, The Roanoke Daily Times, No. XIV/401, 14 January 1896, p. 4.

“Turkey is Stubborn” The San Francisco Call, No. LXXIX/45, 14 January 1896, p. 2.

“Was Adam A Negro?” Aberdeen Herald, No. XIII/46, 17 August 1899, p. 6.

Watkins, John Elfreth "Fertile Field For The Archeologist Attacting Attention of Scientists", The Evening Star, No. 17.002, 13 April 1907, p. 3 [img 23]. [img 65].

“Why a Jap Can Never Be a White Man”, The Washington Times-Herald, No. 1/3, 3 December 1922, p. 4

\section{b. Secondary Sources}

ARENDT, Hannah, "Race-Thinking Before Racism”, The Review of Politics, Vol. 6/1, Cambridge 1944, pp. 36-73.

ÇIRAKMAN, Asl, "Oryantalizmin Varsayımsal Temelleri: Fikri Sabit İmgelem ve Düşünce Tarihi”, Doğu Batı, Vol. 5/20, Ankara 2002, pp. 181-197.

DAVIES, Alan T., Infected Christianity: A Study of Modern Racism, McGill-Queen's University Press, Montreal 1988.

DELANTY, Gerard, Inventing Europe: Idea, Identity, Reality, St. Martin’s Press, New York 1995.

DEVELİ, Tevfik Orkun, "Kum Zencileri: Siber Irkçı Söylemde Türk İmgesi ve Tarihsel Revizyonizm (Stormfront.org Örneği)", Toplum ve Bilim, Vol. 141 Istanbul 2017, pp. 220-240.

EAGLEMAN, David, Incognito-Beynin Gizli Hayatı, çev. Zeynep Arık Tozar, Domingo, Istanbul 2013.

ERKAN BALCI, Elif N., "Metnin Bilinçaltı: Edward Said'de Örtük Şarkiyatç1lık”, Uludağ Üniversitesi Ilahiyat Fakültesi Dergisi, Vol. 22/2, Bursa 2013, pp. 151-167. 1994.

GREENFELD, Liah, Nationalism: Five Roads to Modernity, Harvard University Press, Massachusetts

GORDON, Jacob U., "Black Males in the Civil Rights Movement”, The Annals of the American Academy of Political and Social Science, Vol. 569, Philadelphia 2000, pp. 42-55.

HOOK, Derek, "Fanon and the Psychoanalysis of Racism", Critical Psychology, Juta Academic Publishing, Lansdowne 2004, pp. 114-137. 2006.

ISAAC, Benjamin, The Invention of Racism in Classical Antiquity, Princeton University Press, Princeton

KHALID, Adeeb, "Russian History and the Debate over Orientalism", Kritika: Explorations in Russian and Eurasian History, Vol. 1/4, Washington DC. 2000, pp. 691-699.

MARCHETTI, Silvio, "Avrupalıların Gözüyle Türkler: Mitos ve Yanlış Anlaşılma”, Dünyada Türk Imgesi, ed. Özlem Kumrular, Kitap Yayınevi, Istanbul 2005, pp. 9-12. 


\section{TEVFIK ORKUN DEVELI}

ONGUR, Hakan Ö., Minorities of Europeanization: The New Others of European Social Identitiy, Lexington Books, New York 2015.

ROGERS, James A., "Darwinism and Social Darwinism", Journal of the History of Ideas, Vol. 33/2, Philadelphia 1972, pp. 265-280.

SAID, Edward W., Orientalism, Vintage Books, New York 1978.

SERVANTIE, Alain, "Batılıların Gözünde Türk İmajının Geçirdiği Değişimler: Cehennem Teolojisinden Demokrasi Derslerine”, Dünyada Türk İmgesi, ed. Özlem Kumrular, Kitap Yayınevi, Istanbul 2005, pp. 27-85.

STASZAK, Jean-François, “Other/Otherness”, International Encyclopedia of Human Geography, Elsevier Science, Oxford 2009, [Author postprint], pp. 43-47.

TAJFEL, Henri, "Social Identity and Intergroup Behaviour”, Social Science Information, Vol. 13/2, Paris 1974, pp. 65-93.

TOPÇU, Murat, 19. Yüzyıl Rus Edebiyatında Kafkasya Imgesi, Ph.D Thesis, Istanbul University Institute of Social Sciences, Istanbul 2016.

WÆVER Ole, "Insecurity, Security, and Asecurity in the West European Non-War Community", Security Communities, ed. Emanuel Adler, et al., Cambridge University Press, Cambridge 1998 pp. 69-118.

WEINREICH, Peter, "Rationality and Irrationality in Racial and Ethnic Relations: A Metatheoretical Framework”, Ethnic and Racial Studies, Vol. 8/4, Surrey 1985, pp. 500-515.

YEĞENOĞLU, Meyda, “Avrupa Kimliğinin İdeolojik Arka Planı”, Doğu Batı, Vol. 8/31, Ankara 2005, pp. 89-103. 


\section{ILLUSTRATIONS}



Illustration 1. A depiction of the anatomical and biological differences between Japanese, who are claimed to be of the same race with the Mongols, and white Europeans.

$$
\text { See “Why A Jap...”, p. } 4 .
$$




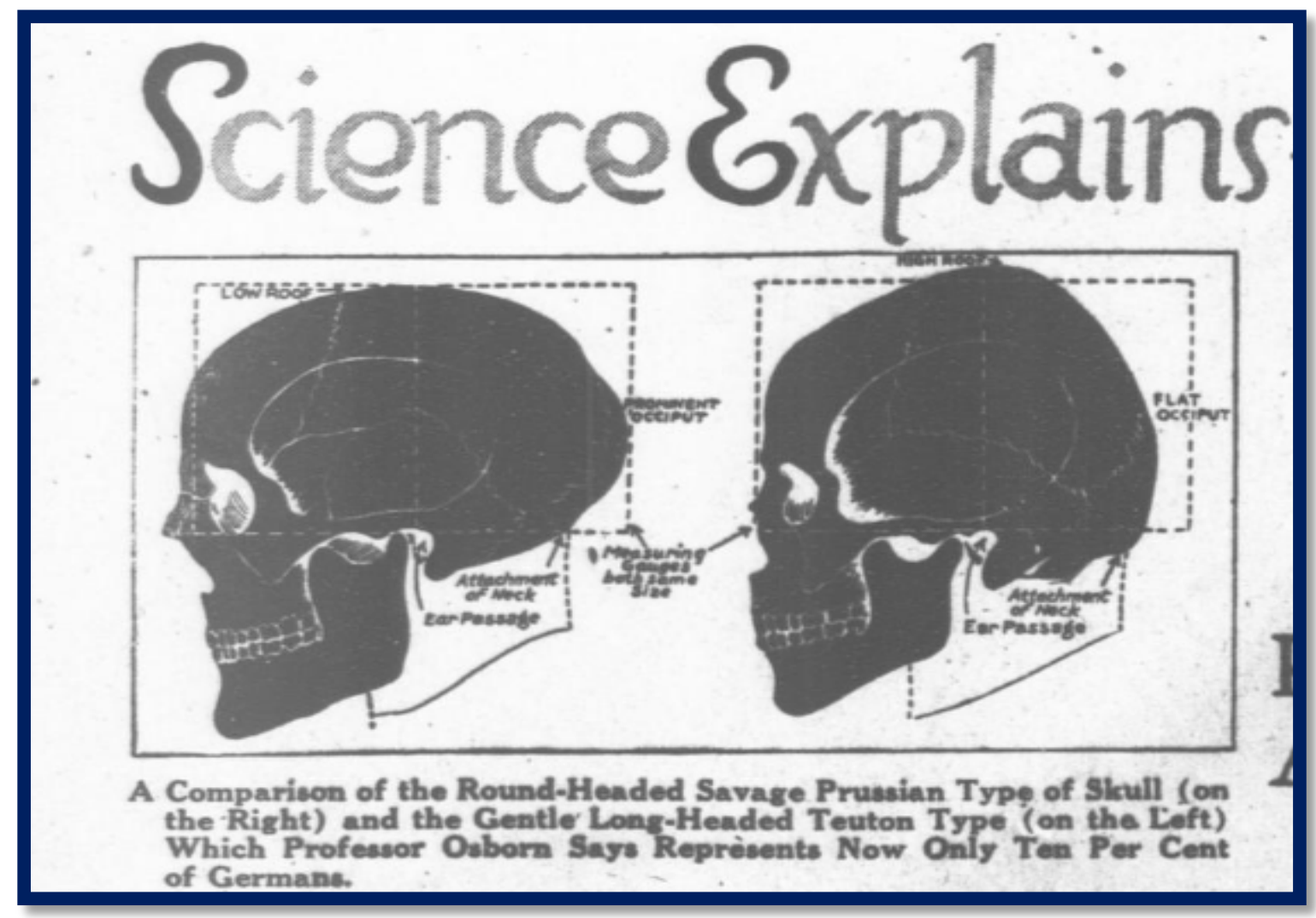

Illustration 2. Depictions of skulls from an article in 1918 claiming that the Prussians were related to the Mongols and therefore were savage and ferocious by nature.

On the left: Long-headed and gentle Teuton type.

On the right: Round-headed and savage Prussian type.

See Ballou, “Science Explains the Prussian Ferocity in War”, p. 2. 


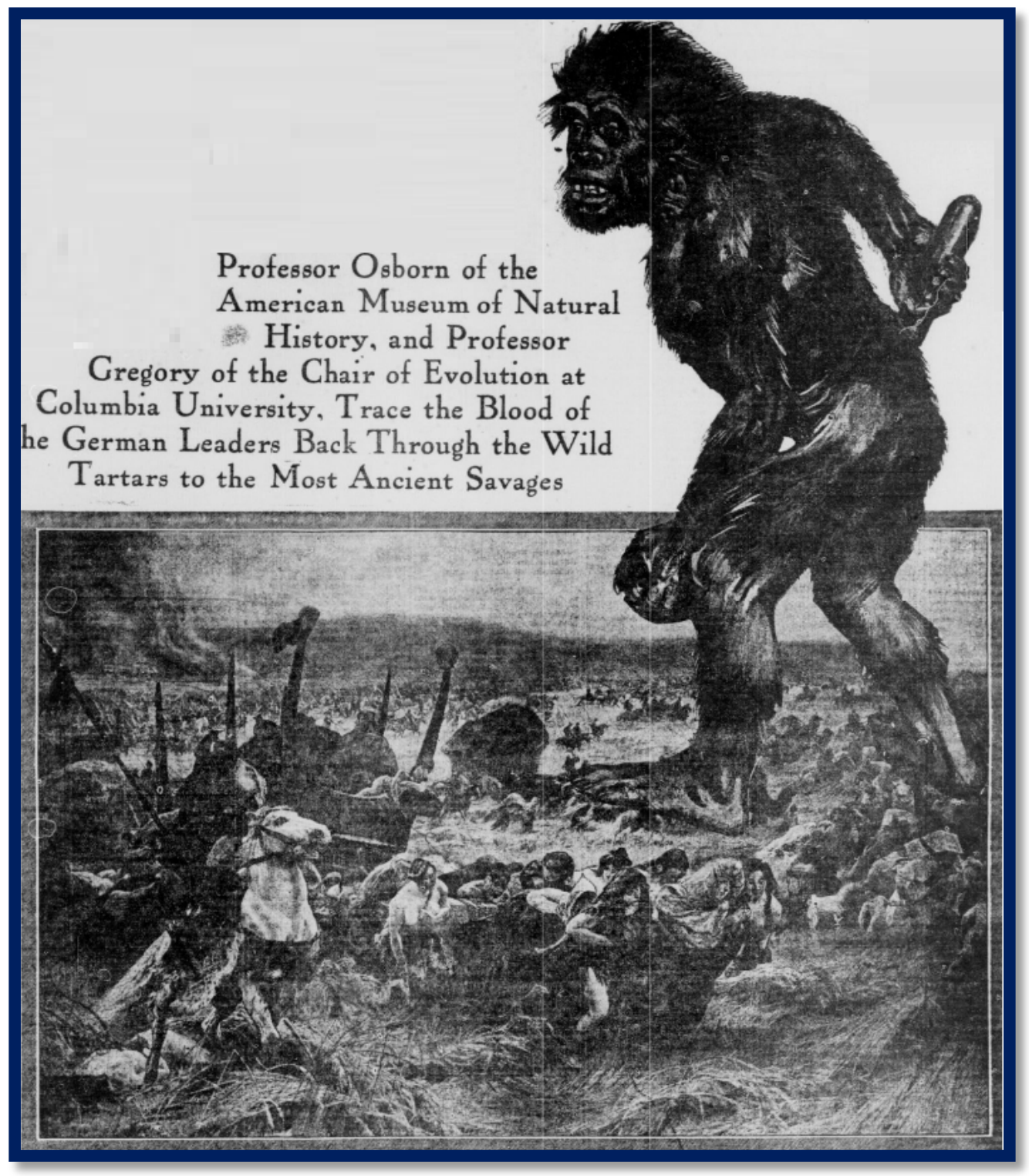

Illustration 3. A depiction of the Homo Heidelbergensis claimed to be the ancestor of the Mongols, Tatars, and Prussians.

See Ballou, “Science Explains the Prussian Ferocity in War”, p. 2. 


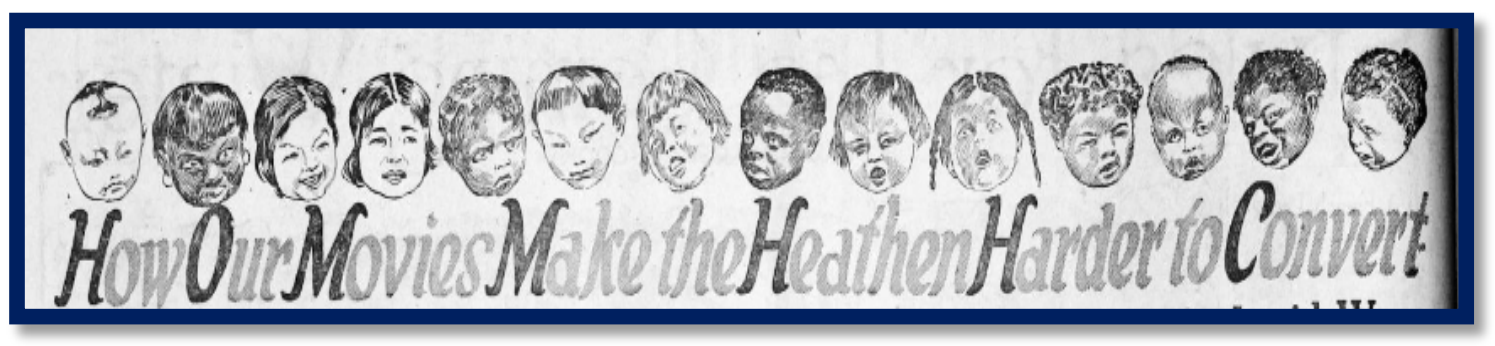

Illustration 4. A depiction of faces of children from non-white and non-religious communities in the local American press.

See “How Our Movies Make The Heathen Harder to Convert”, The Ogden Standard-Examiner, No. 52/94, 8 October 1922, p. 4 [img 32].

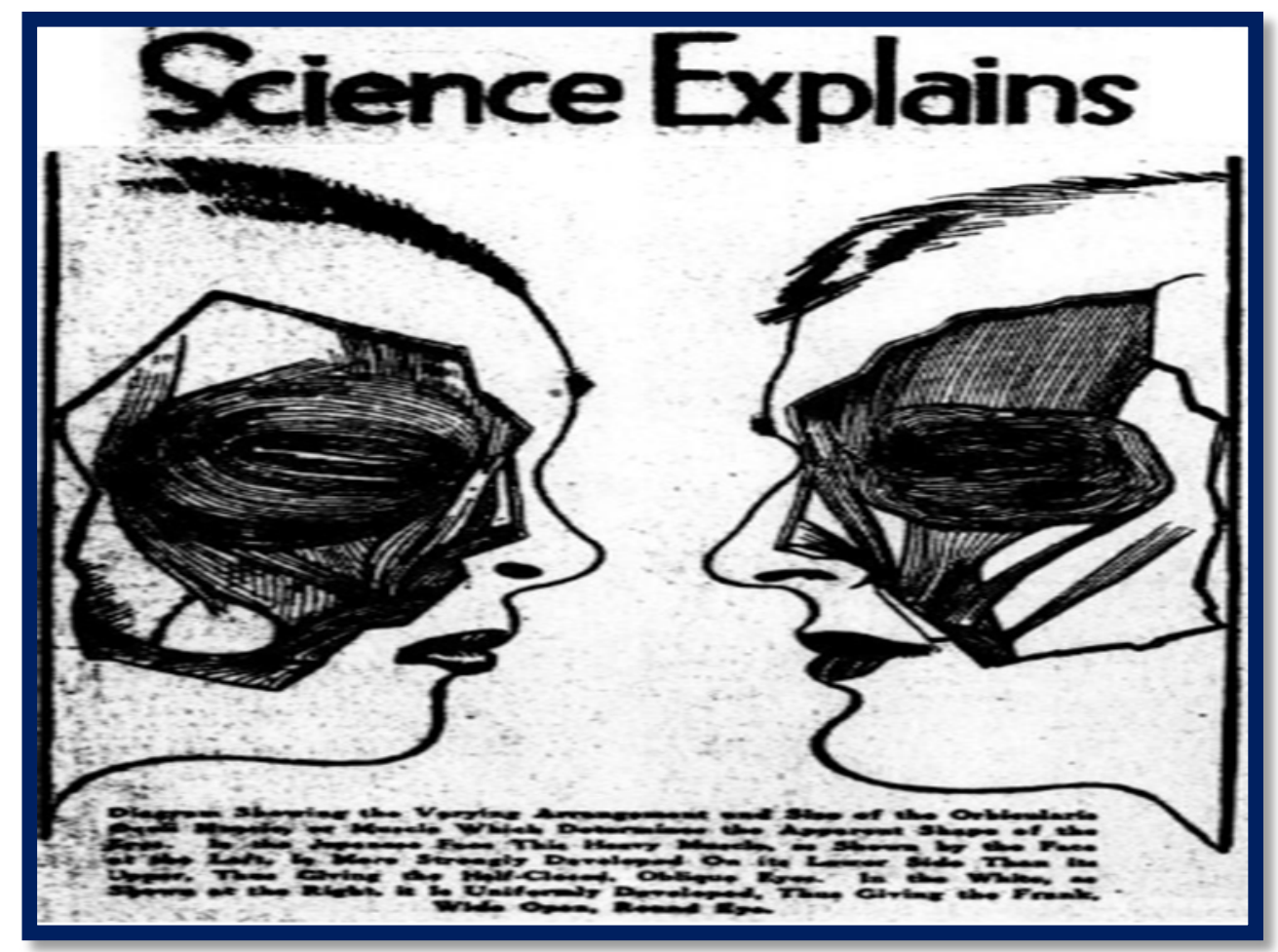

Illustration 5. A depiction in a study that compares the Japanese and the white race according to their facial muscles.

On the left: The drawing depictig the Japanese.

On the right: The drawninde depicting the white race.

See Ballou, “Science Explains Why The Japs...”, p. 6. 


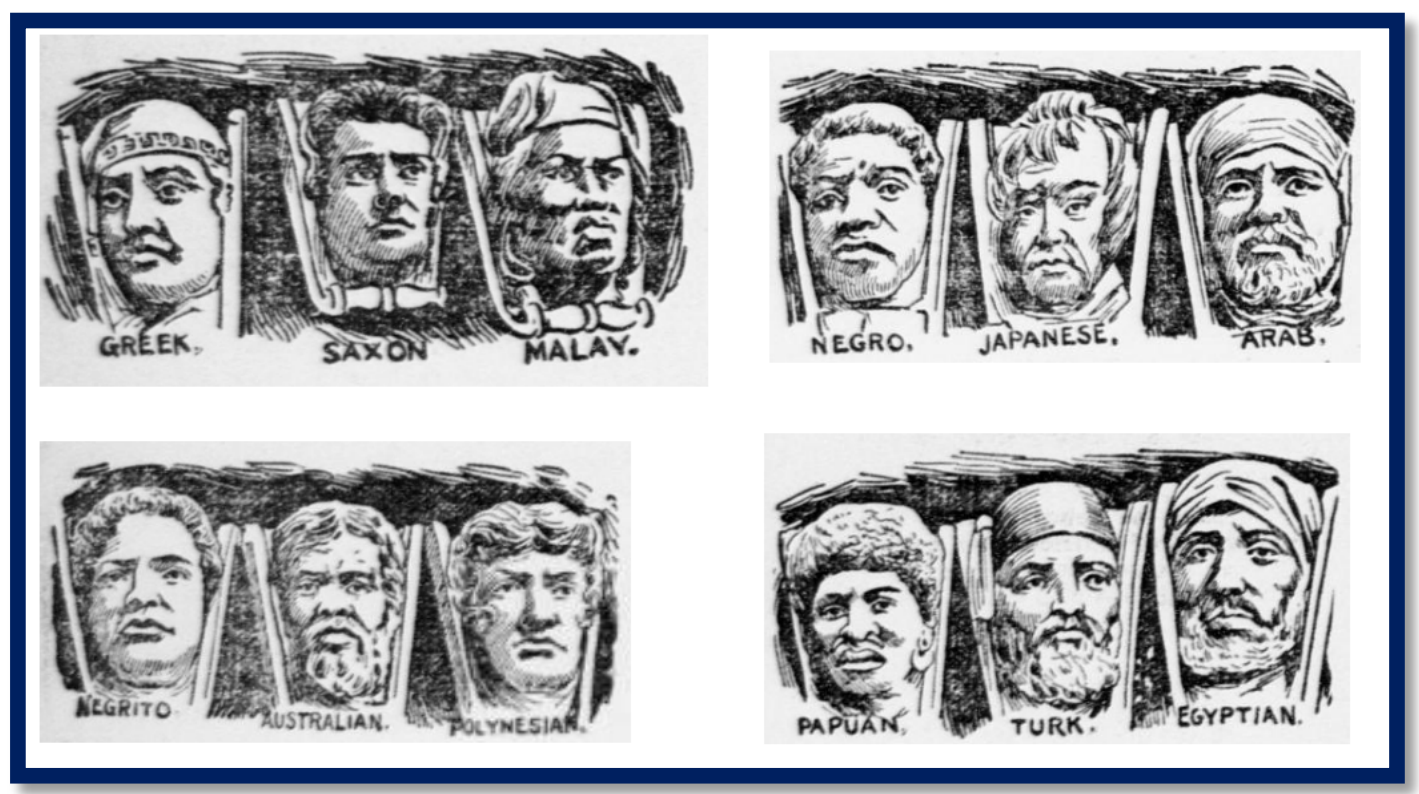

Illustration 6. Representative drawings claimed to be depicting some human races on earth. Bottom right corner, in the middle: The Turk.

See "Faces On The Wall”, p.8. 